\title{
Article
}

\section{Does the Pharmaceutical Sector Have a Coresponsibility for the Human Right to Health?}

\author{
Schroeder, Doris
}

Available at http://clok.uclan.ac.uk/3160/

Schroeder, Doris ORCID: 0000-0002-3633-2758 (2011) Does the

Pharmaceutical Sector Have a Coresponsibility for the Human Right to Health?

Cambridge Quarterly of Healthcare Ethics, 20 (02). pp. 298-308. ISSN 09631801

It is advisable to refer to the publisher's version if you intend to cite from the work. http://dx.doi.org/10.1017/S0963180110000952

For more information about UCLan's research in this area go to http://www.uclan.ac.uk/researchgroups/ and search for < name of research Group>.

For information about Research generally at UCLan please go to http://www.uclan.ac.uk/research/

All outputs in CLoK are protected by Intellectual Property Rights law, including Copyright law. Copyright, IPR and Moral Rights for the works on this site are retained by the individual authors and/or other copyright owners. Terms and conditions for use of this material are defined in the policies page.

\section{CLoK}

Central Lancashire online Knowledge www.clok.uclan.ac.uk

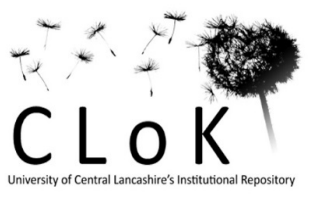




\title{
Does the Pharmaceutical Sector Have a Coresponsibility for the Human Right to Health?
}

\author{
DORIS SCHROEDER
}

The highest attainable standard of health is a fundamental human right, ${ }^{1}$ which has been part of international law since $1948 .^{2}$ States and their institutions are the primary duty bearers responsible for ensuring that human rights are respected, protected, and fulfilled. ${ }^{3}$ However, more recently it has been argued that pharmaceutical companies have a coresponsibility to fulfill the human right to health. ${ }^{4}$ Most prominently, this coresponsibility has been expressed in the United Nations (UN) Millennium Goal 8 Target 4. "In cooperation with pharmaceutical companies, provide access to affordable essential drugs in developing countries." ${ }^{\prime 5}$

In this article, I examine whether this coresponsibility can be justified and, if so, how. I start with a quick reminder of state responsibilities for the human right to health before proceeding to assess whether pharmaceutical companies have obligations beyond those of other corporate sectors. A simile concludes the article.

\section{The Human Right to Health}

In December 1948, the governments of the world came together to assert that each human being

\begin{abstract}
has the right to a standard of living adequate for the health and wellbeing of himself and of his family, including food, clothing, housing and medical care and necessary social services, and the right to security in the event of unemployment, sickness, disability, widowhood, old age or other lack of livelihood in circumstances beyond his control. ${ }^{6}$
\end{abstract}

In 1966, this universal right to health was affirmed by linking it to national legislation. The International Covenant on Economic, Social and Cultural Rights commits State Parties to strive toward securing the highest attainable standard of health for the citizens within their borders. ${ }^{7}$ However, state obligations do not stop at the border. In Article 2, the Covenant affirms the responsibility of each state party

to take steps, individually and through international assistance and cooperation, especially economic and technical, to the maximum of its available resources, with a view to achieving progressively the full realization of the rights recognized in the present Covenant. ${ }^{8}$

This paper was written with support from the Commonwealth of Australia under the International Science Linkages program under grant agreement EF080010 in association with Innova-P2, funded by the European Community's Seventh Framework Programme grant number 217665. Thanks to Julie Lucas, Armin Schmidt, and the participants of the 2010 David C. Thomasma International Bioethics Retreat for comments on an earlier draft and Cathy Lennon for research assistance. 
Table 1 summarizes the main legal instruments governing the right to health.

It is clear that the state bears primary responsibility for ensuring that human rights are respected, protected, and fulfilled. However, that state institutions are primary bearers of responsibility does not mean that other actors have no obligations. The preamble to the Universal Declaration of Human Rights states that

every individual and every organ of society, keeping this Declaration constantly in mind, shall strive by teaching and education to promote respect for these rights and freedoms and by progressive measures, national and international, to secure their universal and effective recognition and observance. ${ }^{9}$

In the following, I ask whether one can reasonably assert that pharmaceutical corporations have a coresponsibility for fulfilling the human right to health and, if so, why.

\section{Primary Obligations of Pharmaceutical Corporations}

Pharmaceutical companies have certain obligations, two of which are primary. The main role of a pharmaceutical company is to develop and produce innovative drugs and services that improve the quality of life of patients. In the current market system, this has to be done in a profitable manner. No other societal actor assumes this responsibility as their main task. Paul Hunt, the former UN Special Rapporteur on the right to health formulates it thus:
A pharmaceutical company that develops a life-saving medicine has performed a vitally important medical, public health and right-to-health function. By saving lives, reducing suffering and improving public health, it has not only enhanced the quality of life of individuals, but also contributed to the prosperity of individuals, families and commu- nities. The company, and its employees, has made a major contribution to the realisation of the rights to life and the highest attainable standard of health. ${ }^{10}$

Discharging this task has to be done within the legal framework. Pharmaceutical companies must, therefore, for instance, not commit any human rights violations, expose employees to unhealthy and unfair working conditions, inflict damage on

Table 1. Legal Instruments: Right to Health

\begin{tabular}{lc}
\hline \multicolumn{1}{c}{$\begin{array}{c}\text { Government obligations } \\
\text { toward their own citizens }\end{array}$} & $\begin{array}{c}\text { Government obligations for } \\
\text { international assistance }\end{array}$ \\
\hline $\begin{array}{c}\text { Universal Declaration of Human Rights, } \\
\text { Art. 25 (1) }\end{array}$ & Declaration of Alma-Ata, Art. II \\
International Covenant on Economic, & UN Committee on Economic, Social \\
Social and Cultural Rights, Art. 12 & and Cultural Rights E/C.12/2000/ \\
Convention on the Elimination of All & Millennium Development Goals 4, \\
Forms of Discrimination against & 5, and 6 \\
Women, Art. 12 & Convention on the Rights of the \\
Convention on the Rights of the Child, & Child, Art. 24 (4) \\
Art. 24 (1-3) & \\
\hline
\end{tabular}




\section{Doris Schroeder}

the environment, or use corruption as a means to promote business or avoid regulation.

One could term compliance with these two primary responsibilities (innovation within the law) as leaving a basic "moral footprint." ${ }^{11}$ One could equate this basic moral footprint with the demands of the UN Global Compact, an initiative to encourage businesses to align their strategies with human rights law. The Compact's main principles are listed in Table 2.

\section{Obligations beyond the UN Global Compact?}

Businesses that align their policies and conduct with the UN Global Compact are usually commended. ${ }^{12}$ Corporations operating globally, say, a car manufacturer or a supermarket chain, that abide conscientiously by the rules of the Compact, would generally be regarded as fulfilling their societal and moral duties. ${ }^{13}$ However, there appears to be a difference when it comes to pharmaceutical corporations. For the latter, there is a growing wave of demands to act beyond the UN Global Compact and actively contribute to providing medicines for those who cannot afford them within the market system. In the introduction, I quoted the UN Millennium Goal 8 Target 4 ("In cooperation with pharmaceutical companies, provide access to affordable essential drugs in developing countries"). Additional impetus comes from nongovernmental organizations (NGOs). For instance, in Investing for Life: Meeting Poor People's Needs for Access to Medicines through Responsible Business Practices, Oxfam states:

There are major shortcomings in the pharmaceutical industry's current initiatives to ensure that poor people have access to medicines. . . . The time is ripe for a bold new approach. The industry must put access to medicines at the heart of its decision-making and practices. . . . [T]he industry's failure to comprehend access to medicines as a fundamental human right enshrined in international law, and to recognise that

Table 2. UN Global Compact: The 10 Principles

\footnotetext{
Human Rights

1. Businesses should support and respect the protection of internationally proclaimed human rights; and

2. make sure that they are not complicit in human rights abuses.

Labor Standards

3. Businesses should uphold the freedom of association and the effective recognition of the right to collective bargaining;

4. the elimination of all forms of forced and compulsory labor;

5. the effective abolition of child labor; and

6. the elimination of discrimination in respect of employment and occupation.

Environment

7. Businesses should support a precautionary approach to environmental challenges;

8. undertake initiatives to promote greater environmental responsibility; and

9. encourage the development and diffusion of environmentally friendly technologies. Anticorruption

10. Businesses should work against corruption in all its forms, including extortion and bribery.
} 
pharmaceutical companies have responsibilities in this context, has prevented the adoption of appropriate strategies. ${ }^{14}$

The UN Millennium Goal 8, the Lancet editorial cited in the introduction, ${ }^{15}$ and Oxfam all assert that pharmaceutical companies have a coresponsibility to fulfill the human right to health. I am interested here in a philosophical justification for this assertion. Potential reasons given in the literature range from enlightened self-interest ${ }^{16}$ to excessive profiteering, ${ }^{17}$ through "you must, if you can"18 to a social contract with society (i.e., patent protection in return for drugs for the poor). ${ }^{19}$

Let us look at philanthropy motivated by enlightened self-interest first. Although a business case can be made for such conduct, for instance to attract better qualified staff, to satisfy ethically aware consumers or to avoid boycotts and "shaming" campaigns, ${ }^{20}$ the benefit of such practices is not limited to pharmaceutical corporations. Hence, it cannot provide justifications for special demands on one corporate sector only. At the same time, if a clear business case could be made for corporate human rights engagement, additional demands would be superfluous, as businesses would engage in such behavior in an effort to be profitable.

Likewise, excessive profits, say in the car industry, do not lead to similar demands to provide cars to the poor. In this context, Bernard Lemoine, DirectorGeneral of France's National Pharmaceutical Industry, said: "I don't see why special effort should be demanded from the pharmaceutical industry. Nobody asks Renault to give cars to people who haven't got one." ${ }^{21}$ Of course, one can point out that life-saving medicines provide for basic human needs; cars normally do not. Still, if this were the only justification, car manufacturers would have a duty to provide suitable cars where they could save lives (e.g., when given to a midwife in rural areas of developing countries). Yet, at the same time, exorbitant prices for basic foods, a prerequisite for human survival, do not normally lead to requests to the food industry to provide advantageously priced food to the poor. Instead state action is demanded, as in August 2009, when the Indian Communist Party (CPI-M) presented demands to the government on how to deal with high rice prices. ${ }^{22}$ It therefore does not seem to be the case that high prices or excessive profits, however one determines these, generally lead to demands for corporations to act beyond the UN Global Compact.

Likewise the principle of "you must, if you can" does not lead to general demands on corporations to help ensure the fulfillment of human rights beyond respecting them. If it did, food producers would have a coresponsibility to supply sustenance to the starving. Or one might hear of demands rather than appeals for donations to publishers or computer companies to share the responsibility for securing the human right to education beyond their standard business role. In fact, no target assigned to the Millennium Goals of reducing hunger or providing universal education identifies any corporate sector responsibility.

This leaves the former UN Special Rapporteur's justification that there is a social contract between the pharmaceutical industry and society, a contract that gives the privilege of patents on the one hand and demands access to drugs for the poor on the other. ${ }^{23}$ But is this really the case? Has the pharmaceutical industry agreed at any point to provide drugs for the poor in return for patent protection? If so, it is not clear how, where, or when this occurred. However, 


\section{Doris Schroeder}

Hunt's justification for the special human rights obligations of the pharmaceutical industry does refer to an important element, namely, intellectual property rights protection.

\section{Intellectual Property Rights and the Human Right to Health}

The crux of the matter is best illustrated by comparing a company that produces antiretroviral drugs (ARVs) with a company that produces food. In 2008, the yearly cost of providing second-line $\mathrm{ARVs}^{24}$ to AIDS patients was US $\$ 1,105$ per patient in low income countries. ${ }^{25}$ These drugs were still under patent protection. Hence, no cheap generic alternatives were available. To feed a child to protect him or her from starvation or severe malnutrition costs US\$630-1,260 per year, depending on the country and the setting (and assuming the child has no additional medical complications; personal communication, Miltos Ladikas, figures from Action Contre La Faim (ACF), Paris on October 29, 2009). Both the right to health and the right to food are enshrined in the same article of the Universal Declaration of Human Rights, cited at the outset of this article.

Why then is Unilever, one of the largest multinational food producers, not asked regularly and pressingly to contribute to achieving global food security? What is the difference to, say, Novartis, Pfizer, or Glaxo Smith Kline's potential to contribute to global health? Both sectors service basic human needs, and the costs of achieving survival are comparable.

Essentially the answer is contained in one word: patents, or, more broadly, intellectual property right protection. Barring entry to the market for copied products for a specified interval provides innovators with a chance to charge monopoly prices. ${ }^{26}$ Among those who benefit from intellectual property rights protection, the pharmaceutical industry is the only industry that trades in goods that are required to satisfy basic human needs. ${ }^{27}$

Films, software, books, designs, circuit layouts, computer programs, new technical inventions, and so forth, none of these satisfy basic human needs. The only exception is the seeds industry, which does benefit from intellectual property rights protection while providing for basic human needs. However, considerable farmers' rights against multinational corporations have been established under the International Treaty on Plant Genetic Resources for Food and Agriculture (ITPGR). This treaty exempts a number of basic food and seed crops from patenting and makes them accessible to all member states through a facilitated system. ${ }^{28}$ As there are no such exemptions for the pharmaceutical industry, and countries face serious difficulties when they invoke the compulsory licensing exemption ${ }^{29}$ of the Trade-Related Aspects of Intellectual Property Rights Agreement (TRIPS) agreement, ${ }^{30}$ the pharmaceutical sector is unique in benefiting from monopoly pricing powers at the same time as providing for a basic human need. However, the situation is more complicated, and the justification for pharmaceutical obligations is more subtle than a social contract with patents at one end and access to drugs for the poor at the other.

It was shown in the Singer and Schroeder article in this Symposium that the human right to life trumps any rights of inventors to have their intellectual property protected. ${ }^{31}$ Pharmaceutical corporations cannot therefore argue that the human right to health and the natural right to intellectual property are of equal value. The latter must give way to the former when they are incompatible. 
However, it is one thing to build the possibility of compulsory licensing into international law but quite another to assert a coresponsibility for securing the human right to health. The former would be covered by the UN Global Compact, which demands legal compliance; the latter would not.

\section{Coresponsibility for the Human Right to Health?}

To recap: I am interested in the question of why the pharmaceutical sector has been assigned a coresponsibility to secure the human right to health. We can disregard any arguments from benevolence or philanthropy because they would apply to all corporate sectors. We can also ignore any arguments from unique ability, as other companies or entities have unique abilities to contribute, for instance, to achieving the Millennium Goals (e.g., food companies to eradicate hunger [goal 1], publishers and computer firms to contribute to universal education [goal 2]). Instead, we must keep a link between patents and basic survival needs. A strong argument centering on harm would assert that "patents are killing people $\mathrm{e}^{\prime \prime 32}$ who would live if the system were abandoned. A weaker argument would assume that the patent system benefits many, but also directly harms some individuals, who are owed some redress.

Although philosophers have been debating the intricacies of moral theories for millennia, there is broad agreement that avoidable deaths constitute a harm ${ }^{33}$ and that foreseeable harm must be avoided. ${ }^{34}$ In virtue theory "Being able to live to the end of a human life of normal length; not dying prematurely" ${ }^{\prime 35}$ is given prime importance, as the first human capability that exerts a moral claim on others. ${ }^{36}$ In utilitarian theory, it is taken for granted that "[s]uffering and death from lack of food, shelter and medical care are bad" and that we must "prevent something bad from happening. ${ }^{\prime \prime 37}$ In rights-based theory it is assumed that the "state of nature has a law ... to govern it; ... no one ought to harm another in his life." 38

What can one answer in response to a general attack on the patent system as generating "profits that kill?"39 The obvious answer is that profits for the pharmaceutical industry are not the main justification for the patent system. As is made clear in the preamble of the 1970's Patent Cooperation Treaty, which covers 142 countries, ${ }^{40}$ the reason governments support intellectual property rights is because patents "make a contribution to the progress of science and technology" and "facilitate and accelerate access by the public to the technical information contained in documents describing new inventions."

Although patents are "a tortured solution to the problem of providing a public good, ${ }^{\prime 41}$ no feasible alternative to a patent system seems to be on the table. This does not mean that the system could not be improved (see Thomas Pogge and Aidan Hollis' epilogue to this Symposium). However, without some form of patent system, more people could die as a result of lack of pharmaceutical innovation. $^{42}$

What can one say in response to the weaker argument that the patent system benefits many but directly harms others to whom redress is owed? At first sight, this does not seem to be reasonable either. Patents do not form a significant obstacle to access to essential medicines. A study by Amir Attaran found that in 65 low- and middle-income countries, where 4 billion people live, patenting is rare for the 319 products on the World Health Organization's Model List of 


\section{Doris Schroeder}

Essential Medicines. Only 17 essential medicines are patentable, and these are, in practice, rarely patented, so that overall patent incidence is low (1.4\%) and concentrated in larger markets. ${ }^{43}$ Indeed, low-cost pharmaceutical interventions that could prevent at least two thirds of today's infant and maternal mortality are known and available at affordable prices. ${ }^{44}$

However, as the current UN Special Rapporteur on the Right to Health, Anand Grover, has noted,

'[t]he inability of populations to access medicines is partly due to high costs'; and that TRIPS and FTAs [Free Trade Agreements] have had an adverse impact on prices and availability of medicines, making it difficult for countries to comply with their obligations to respect, protect, and fulfil the right to health. ${ }^{45}$

An example, which was also included in the Schroeder and Singer piece in this Symposium: before 2005, Indian law only allowed patents on processes, not on products. ${ }^{46}$ As a result, India had a thriving generic pharmaceuticals industry that supplied copies of patented medicines cheaply throughout the world's poor regions. However, in 1994 India signed up to TRIPS and as a result, was required to introduce patents on products by January 2005. This change to Indian patent rules affects the world's poor in two ways; directly by undercutting the supply of affordable medicines and indirectly by removing the generic competition that reduced the cost of brand-name medicines. ${ }^{47}$ These poor populations are now worse off, and possibly dying, because of a tightening of the existing intellectual property system. At least some of the 10 million avoidable deaths alerted to in the editorial can therefore be attributed to current developments in the patent system. Hence, we do have a direct, recent harm, which relates to the patent system and which could have been avoided without the adoption of the TRIPS agreement. The argument that intellectual property rights are a tortured solution to providing a social good, but alas necessary, does not work for those poor who may die because of the TRIPS regime. Prior to its adoption, pharmaceutical companies researched, developed, and produced medical interventions. It was not necessary to adopt TRIPS to provide incentives for pharmaceutical research. But again, the problem is more subtle than this.

High prices of drugs under patent protection are not the only problem endangering poor people's health. Given that the pharmaceutical industry operates almost exclusively within the profit-making sector in line with their primary obligation in a market system, diseases that burden the poor are often not investigated in the first place. As noted in the introduction to this Symposium, one can therefore speak of an accessibility problem (i.e., that existing drugs are priced beyond the reach of the poor) and an availability problem (i.e., that drugs are not being developed to address the needs of the poor). ${ }^{48}$ It is assumed that stronger patent protection in countries like India, Brazil, and South Africa will lead to the growing interest of pharmaceutical companies in so-called neglected diseases, given that purchasing power in those countries is significantly on the increase. Hence, although TRIPS creates direct harm for those poor people who can no longer access cheap generic copies of patented drugs in, say, India today, it contributes (at least potentially) to resolving the neglected diseases issue. Going back to the pre-TRIPS regime is therefore no straightforward solution, morally, if one considered future benefit. At the same time, the 
pharmaceutical sector benefits from a system that imposes direct harm, for instance, on the current severely poor in India who would have had access to generic copies of patented drugs without TRIPS.

Corporate social responsibility is usually discussed within the realm of law, enlightened self-interest, or benevolence. Either a duty is instructed by law (e.g., health and safety for workers) or self-interest (e.g., continuous education of staff) or benevolence (e.g., donations) or a mixture of the three. But for one business sector, namely, those companies that benefit from patents on goods required to satisfy basic needs, a fourth realm must be added, namely, a duty of redress for harm from which one benefits.

What follows from this? The creators of the international intellectual property rights system are policymakers, pressured by lobbyists, among them the pharmaceutical industry. The strongest duty to reduce any foreseeable harm from the current patent system lies with its creators, who have to fine-tune the system to a degree of maximum benefit and minimum harm. This work has begun, as the article by Tikki Pang in this Symposium has shown. ${ }^{49}$ However, the system has not only creators but also beneficiaries, most notably the pharmaceutical industry and those who are affluent enough to enjoy the fruits of scientific progress. Duties of redress for harm imposed on some that achieve benefits for others apply to both these groups. It is here that one can most reasonably apply the "one ought, if one can" maxim. Pharmaceutical corporations in affluent countries are better placed than civil society to have a fast impact on the health of the poor. They must therefore discharge their responsibility to reduce the harm generated by a system from which they benefit, that is, this is not a supererogatory act. ${ }^{50}$

We now have an answer to the question posed at the outset: does the pharmaceutical industry have a coresponsibility for ensuring the human right to health? Yes, it does, as it benefits from a system that foreseeably harms some of the severely poor and therefore owes redress. Yet, this is not a full coresponsibility for the human right to health per se (exempting duties for benevolence). It is a responsibility to provide targeted redress in the one area where they benefit from a system that creates harm: the area of access to patented medicines by those who have now been barred as a result of the TRIPS regime.

\section{Conclusion}

Before the advent of modern medicine and drug development, one might compare people's lives with floating on wooden rafts on a large, unpredictable ocean. Small cold or flu waves would throw off the weak into the ocean, and larger pneumonia or pestilence waves would throw off even the strong. The ocean would be teeming with small rafts, all being in the same position, fairly defenseless against disease waves. Slowly, more reliable boats would be created, first through traditional medicine and later by the progress of science (e.g., an unpatented polio vaccine). Then, over a period of time, some nation states would create huge ocean liners, almost oblivious to disease waves. Although the creators of the ocean liners were states, certain operators would obtain rent from all passengers, who sailed along safely with little danger of being thrown into the ocean prematurely. Most of those drifting on small rafts were no worse off than before, but they would most reasonably wonder why they were left behind on a raft. More worryingly though, the ocean liners would create an unwanted side 
effect. They would create new waves that would throw some off their rafts when they would have been able to hang on before (e.g., TRIPS and India). It is these waves that create a duty beyond philanthropy for the pharmaceutical sector, a duty to redress for harm done, a limited coresponsibility for the right to access to life-saving medicines.

\section{Notes}

1. WHO. Constitution; available at http://www.who.int/governance/eb/constitution/en/index. html (last accessed 1 Jul 2010).

2. Universal Declaration of Human Rights, Article 25(1); 1948; available at http:/ /www.un.org/en/ documents/udhr/index.shtml\#a25 (last accessed 1 Jul 2010).

3. UN Special Rapporteur on the Right of Everyone to the Enjoyment of the Highest Attainable Standard of Physical and Mental Health (henceforth, UN Special Rapporteur on the right to health) A/61/338; available at http://www.ggp.up.ac.za/human_rights_access_to_medicines/ additional/2009/hunt\%20reports/HuntReportAccesstoEssentialMedicinesandMaternalMortality. pdf; also E/CN.4/2006/48; available at http:/ / daccess-dds-ny.un.org/doc/UNDOC/GEN/G06/ 114/69/PDF/G0611469.pdf?OpenElement; also E/CN.4/2006/48Add.2; available at http://www2. ohchr.org/english/bodies/chr/docs/62chr/E.CN.4.2006.48.Add.1.pdf; also E/CN.4/2005/51/ Add.3; available at http://daccess-dds-ny.un.org/doc/UNDOC/GEN/G05/106/45/PDF/G0510645. pdf?OpenElement; also E/CN.4/2004/49/Add.1; available at http://www.unhchr.ch/Huridocda/ Huridoca.nsf/e06a5300f90fa0238025668700518ca4/5860d7d863239d82c1256e660056432a/\$FILE/ G0411390.pdf (last accessed 1 Jul 2010).

4. Editorial: Right-to-health responsibilities of pharmaceutical companies. The Lancet 2009;373:1998. For the sake of brevity and readability, we shall henceforth shorten the expression "the human right to the highest attainable standard of health" to "the human right to health."

5. UN Millennium Goal 8, Target 4; available at http://www.un.org/millenniumgoals/global.shtml (last accessed 1 Jul 2010).

6. See note 2, Universal Declaration of Human Rights 1948.

7. United Nations Committee on Economic, Social and Cultural Rights, E/C.12/2000/4. (General Comments) General Comment No. 12; 2000; available at http://www.unhchr.ch/tbs/doc.nsf/ (symbol)/E.C.12.2000.4.En (last accessed 1 Jul 2010).

8. International Covenant on Economic, Social and Cultural Rights, Art. 2, emphasis added; available at http://www2.ohchr.org/english/law/cescr.htm\#part2 (last accessed 1 Jul 2010).

9. Universal Declaration of Human Rights 1948: Preamble, emphasis added; available at http:// www.un.org/en/documents/udhr/index.shtml\#a25 (last accessed 1 Jul 2010).

10. Report of the Special Rapporteur on the Right of Everyone to the Enjoyment of the Highest Attainable Standard of Health, Paul Hunt-Annex-Mission to Glaxosmithkline 2009; 11, para 35; available at http://198.170.85.29/Paul-Hunt-report-on-GSK-5-May-2009.pdf (last accessed 10 Jul 2010).

11. Leisinger KM. Capitalism with a human face: The UN Global Compact. The Journal of Corporate Citizenship 2007;28:12.

12. Spitzeck H, Pirson M, Amann W, Khan S, von Kimakowitz E, eds. Humanism in Business. Cambridge, UK: Cambridge University Press; 2009.

13. I exempt animal experimentation from this discussion.

14. Oxfam. Investing for Life: Meeting Poor People's Needs for Access to Medicines through Responsible Business Practices, Briefing Paper 109; 2007:1; available at http://www.oxfam.org/sites/ www.oxfam.org/files/bp109-investing-for-life-0711.pdf (last accessed 5 Jul 2010).

15. See note 4, Editorial 2009:1998.

16. See note 11, Leisinger 2007:12.

17. Joseph S. Pharmaceutical corporations and access to drugs: The fourth wave of corporate human rights scrutiny. Human Rights Quarterly 2003;25(2):425-52.

18. Dunfee TW. Do firms with unique competencies for rescuing victims of human catastrophes have special obligations? Corporate responsibility and the AIDS catastrophe in Sub-Saharan Africa. Business Ethics Quarterly 2006;16(2):185-210.

19. See note 10, Hunt 2009:11, para 36. 


\section{Pharmaceutical Sector and Human Right to Health}

20. Leisinger KM. On Corporate Responsibility for Human Rights 2006:17; available at http:// www.unglobalcompact.org/docs/news_events/9.6/corpresforhr_kl.pdf (last accessed 5 Jul 2010).

21. Bulard M. Apartheid of pharmacology. Le Monde Diplomatique; available at http:// mondediplo.com/2000/01/12bulard (last accessed 5 Jul 2010).

22. CPI-M to launch agitation against price rise, drought. Thaindian News 2009 Aug 27; available at http://www.thaindian.com/newsportal/politics/cpi-m-to-launch-agitation-against-price-risedrought_100238934.html (last accessed 5 Jul 2010).

23. See note 10, Hunt 2009:11, para 36.

24. Second-line drugs are used when the standard therapy fails and are often much more expensive than the first drug of choice.

25. Avert (not dated). Aids, Drug Prices and Generic Drugs; available at http://www.avert.org/ generic.htm (last accessed 5 Jul 2010).

26. Danzon PM, Towse A. Differential pricing for pharmaceuticals: reconciling access, R\&D and patents. International Journal of Health Care Finance and Economics 2003;3:183-205, at p. 185.

27. In line with Art. 25(1), see note 2 above, we take basic human needs to comprise food, clothing, housing, and medical care.

28. Helfer L. Intellectual property rights in plant varieties: International legal regimes and policy options for national governments, Part IV, United Nations FAO Legislative Study 85 2004; available at http://www.fao.org/docrep/007/y5714e/y5714e05.htm (last accessed 5 Jul 2010).

29. With a compulsory license, a government forces a patent holder to allow the manufacture of generic copies of a drug at significantly reduced prices.

30. SciDev. Drug licences all for the poor, says Thai minister; available at http://www.scidev.net/en/ news/drug-licences-all-for-the-poor-says-thai-minister.html (last accessed 5 Jul 2010).

31. Schroeder D, Singer P. Access to life-saving medicines and intellectual property rights: An ethical assessment. Cambridge Quarterly of Healthcare Ethics, this issue, 279-289.

32. Bunting M. Profits that kill. The Guardian 2001 Feb 12; available at http://www.guardian.co.uk/ world/2001/feb/12/wto.aids (last accessed 5 Jul 2010).

33. Nagel T. Death. In: Nagel T. Mortal Questions. Cambridge, UK: Cambridge University Press; 1979; Feldman F. Some puzzles about the evil of death. The Philosophical Review 1991;100:205-27.

34. Because of constraints of space, I do not include here possible provisos; e.g., foreseeable harm with the informed, voluntary consent of the potentially injured party may be justifiable.

35. Nussbaum M. Women and Human Development: The Capabilities Approach. Cambridge, UK: Cambridge University Press; 2000:78.

36. See note 35, Nussbaum 2000:83.

37. Singer P. The Life You Can Save. Melbourne: Text Publishing Company; 2009:15.

38. Locke J. The Second Treatise of Civil Government, Chapter II, Of the State of Nature, Section 6. 1690; available at http://www.milestonedocuments.com/documents/full-text/john-lockes-secondtreatise-on-civil-government (last accessed 5 Jul 2010).

39. See note 32, Bunting 2001.

40. World Intellectual Property Organization. Treaties and Contracting Parties; available at http:// www.wipo.int/treaties/en/ShowResults.jsp?lang=en\&treaty_id=6 (last accessed 5 Jul 2010).

41. Scotcher S. Innovation and Incentives. Cambridge, MA: MIT Press; 2004:34

42. Hollis A, Pogge T. The Health Impact Fund: Making New Medicines Accessible for All. Incentives for Global Health; 2008; available at http://www.yale.edu/macmillan/igh/hif_book.pdf (last accessed 5 Jul 2010).

43. Attaran A. How do patents and economic policies affect access to essential medicines in developing countries? Health Affairs 2004;23(3):155-66.

44. Department of International Development. Increasing Access to Essential Medicines in the Developing World. London: Department for International Development; 2004.

45. Grover A. Promotion and Protection of all Human Rights, Civil, Political, Economic, Social and Cultural Rights, including the Right to Development, a Report of the Special Rapporteur on the Right of Everyone to the Enjoyment of the Highest Attainable Standard of Physical and Mental Health. United Nations; 2009: A/HRC/11/12 points 14 and 94; available at http:/ /www2.ohchr.org/ english/bodies/hrcouncil/docs/11session/A.HRC.11.12_en.pdf (last accessed 5 Jul 2010).

46. Pogge T, Schroeder D. Why we need a new approach to pharmaceutical innovation: A pragmatic answer to a moral question. In: Noppen M, Wynants M, eds. In Sickness and Health: The Future of Medicine. Brussels: Vrije Universiteit Brussel Press; 2009:197-213. 


\section{Doris Schroeder}

47. Editorial: India's choice. New York Times 2005 Jan 18; available at http:/ /www.nytimes.com/2005/ 01/18/opinion/18tues2.html (last accessed 5 Jul 2010).

48. Selgelid M, Sepers EM. Patents, profits, and the price of pills: Implications for access and availability. In: Illingworth P, Schuklenk U, Cohen JC, eds. The Power of Pills: Social, Ethical and Legal Issues in Drug Development, Marketing and Pricing Policies. London: Pluto Press; 2006:153-63, at p. 153.

49. Pang T. Developing medicines in line with global public health needs: The role of the World Health Organization. Cambridge Quarterly of Healthcare Ethics, this issue, 290-297.

50. In this limited space, one cannot detail how this could or should be done. Klaus Leisinger and Karin Schmitt give some examples in the next contribution to this Symposium. However, it is also worth emphasizing the importance of supporting reform plans to modify the intellectual property rights system, a point eloquently made by Aidan Hollis and Thomas Pogge in the epilogue to this Symposium. 